\title{
The shopping mall as an emergent public space in Turkey
}

\author{
Feyzan Erkip \\ Faculty of Art, Design and Architecture, Bilkent University, 06800, Ankara, Turkey; \\ e-mail: feyzan@bilkent.edu.tr
}

Received 21 June 2002; in revised form 23 December 2002

\begin{abstract}
The shopping mall as a part of the recent transformations in Turkish urban lifestyle is the focus of this research. Characteristics of the Turkish way of using shopping malls, and their social and spatial consequences, are investigated and analyzed through a case study in Ankara, the capital of Turkey. The field survey was carried out in Bilkent Shopping Center, a newly built shopping mall in a suburban area which was also established recently as a high-income housing settlement. This shopping mall is an appropriate example of spatial transformations under the influence of global forces, which may also give clues about changes in urban lifestyle. A field survey was carried out through user surveys, and various observations are used to enrich the analysis. The results indicate that the shopping mall as a postmodern site matched the changing shopping and consumption requirements of Turkish urban citizens. The development of the shopping mall turns out to be timely for the Turkish urban citizen searching for modernity through new identity components in consumption patterns. Some benefit from this development more than others, for example, working women, indicating the process of feminization of the flaneur. However, these sites simultaneously produce a new arena of negotiation and conflict as well, creating new forms of exclusion-particularly for the urban poor. Although malls appear more public and democratic than the streets for the time being, the potential for segregation is implicit in their private character.
\end{abstract}

\section{Introduction: the Turkish context}

The shopping mall, as a part of the recent transformations in Turkish urban lifestyle is the focus of this paper. Although shopping mall development is not a recent process in many countries - particularly the USA and the United Kingdom - it took a few more decades for malls to appear as part of the urban scene in Turkey. The timing is very appropriate, both for the developers and for consumers searching for new consumption patterns and sites. Turkish people have adapted to using shopping malls eagerly and regularly, although the development process is quite recent. The factors affecting the use and appeal of the mall in Turkish society were examined in an earlier study (Erkip, 2002). In this paper, the mall is further analyzed as the site of new Turkish urban modernity as well as a potential site of new segregation trends. In this second respect, Ankara deserves closer attention because of its role as the capital of the Turkish Republic in the formation of modernity in Turkey; this process has been established as a national project.

Characteristics of the Turkish way of using shopping malls, as well as social and personal meanings attached to this new site, are investigated and analyzed through a case study in Ankara. The Bilkent Shopping Center, a newly established shopping mall near an upper-income suburban area, was chosen for the empirical part of this study. This shopping mall is an appropriate example of spatial transformations under the influence of global forces, which may also give clues about changes in urban lifestyle. In order to trace social and spatial imprints of globalization on the locality, one requires a thorough understanding of local context - in this case Turkish urban society.

Turkish society has been transforming rapidly since the mid-1980s because of economic restructuring. The Turkish economy registered high rates of growth from 1980 to 1993 , aided by the structural reform in the economy that placed emphasis on 
a liberal, market-oriented, and outward-looking development strategy. The result has been the rise of corporate power, and the introduction of foreign capital through partnership with Turkish firms which has made the large investments required by new consumer demand possible. Increases in average income and organized financial support for consumption through bank credit have added to the consumption potential of Turkish citizens. Gross national product (GNP) per capita doubled between 1980 and 1998 (DIE, 2002), although it was reduced from US \$2986 to \$2160 in 2001 as a result of the latest economic crisis (Radikal 2002). Average consumption expenditures have also increased, particularly in urban Turkey (DIE, 1997), and reached US \$1378 per capita in 1997 (Tokatli, 1999). However, Turkey is still a poor country compared with other developing countries, taking into account purchasing power parity of US \$6126 GDP per capita (Demirel, 2001). Yet, the banking and financial system has long been ready to support this consumption. The number of credit cards, and their share of consumption expenditure, have significantly increased since 1992 when credit cards were first issued, and currently there are approximately 14 million card users (BKM, 2001; Globus 2002). Many banks allow people to pay in installments, and large companies or groups of shops also issue payment-by-installment cards. Although consumption potential is disturbed by frequent economic crises in Turkey, these consumption patterns are expected to persist. The demand for installment cards and bank credits for consumer goods increased by about 50\% in 2001 (Radikal 2001d). The last crisis, in February 2001, has been influencing all the sectors of the Turkish economy and producers have reduced their prices by up to $75 \%$ to revive the market as consumption is considered the prime mover of the economy (Radikal 2001b). Crisis conditions turned out to influence the consumption trends of necessities - food and hygienic products - as people tend to buy smaller amounts and cheaper products (Ekonomist 2001). However, although all segments of the population complain about the recent situation, the malls attract more visitors than ever before. For instance, during the last week of December 2001, many malls in Ankara and Istanbul attracted incredibly high numbers of visitors, up to 100000 people per day. A special supplement of a daily newspaper gave an optimistic account of consumption trends, announcing the openings of new malls and international brands entering the Turkish market (Radikal 2001a). The same source claims that a particular mall in Istanbul-Akmerkez-has been attracting 1.5 million visitors per month even during the crisis. It seems that the function of the mall is not limited to consumption. In this paper I investigate the nature of mall visits, and suggest that the mall satisfies the modernity requirements of various segments of Turkish urban society as a new public space.

Crowding, traffic problems, and lack of pedestrian safety in the city center served to create demand for these new areas. Traffic is a serious problem in Turkey, with a lot of accidents - even in the cities. The increasing number of private cars and lack of sufficient parking provision make the pavements an easy substitute for parking lots. Pedestrians make many complaints regarding the invasion of pavements by cars, and insufficient maintenance and infrastructure make walking difficult, especially on rainy days, and some injuries result (Odekan, 2001). Gokariksel (2001) notes that malls in Istanbul are seen as a solution to the increasing problems of Istanbul, including incivility in the streets as well as social segregation.

What the aggregate figures fail to indicate is the fact that rich people in large cities have been associated with a disproportionate share of the national income. Incomedistribution figures indicate a significant inequality in large cities. The income share of the highest and the lowest quintiles in the two biggest metropolises-Istanbul and Ankara - was seriously disproportionate even before the recent economic crisis. According to the latest official data (for 1994), the percentages were $4.2 \%$ for the lowest and $64.1 \%$ for 
the highest quintile in Istanbul and 6.3\% and 46.0\% in Ankara (DIE, 1998). Average consumption expenditures - again, disproportionately distributed across quintiles-in these two cities are still seven times that in the remaining urban areas of Turkey (DIE, 1997). Ownership of private cars in these two cities is double Turkey's average (DIE, 2002). However, economic inequalities are not the only indicator of segregation in Turkish cities. Beginning in the 1950s, large cities attracted a significant number of people from the rural areas and small towns. According to the 1997 Census, $65 \%$ of the Turkish population live in urban areas, with $42 \%$ living in cities with a population higher than 100000 (Demirel, 2001). Most of the migrants live in illegal housing settlements called gecekondu in Turkish, meaning 'built in one night'. In 1995, about $35 \%$ of the urban population lived in squatter settlements (Keles, 2000). The rate of migration was very high until the late 1970s and consequently large cities, unable to cope with the population increase, had a dual structure with both squatter settlements and formal apartment blocks. [For an account of the physical and social differences between these two settlement types see Ayata (1989).] Yet, until recently, there were no adverse effects of this duality [though see Erman (2001) for the change in attitude against squatters which became increasingly negative because of the political environment]. Poverty, which is spatially represented by squatters in urban Turkey, has long been the main reason for 'otherness' (Koray, 2001); yet it did not evoke negative feelings until recently.

The group with the highest incomes has constituted the basis of a new consumer culture and lifestyle under the influence of global consumption patterns. The emerging paradox of Turkish citizens appears in such a way that "while most people, given the chance, would opt for Western standards of living, globalization has weakened the equitable delivery by the state of the requirements behind those standards" (Cizre-Sakallioglu and Yeldan, 2000, page 497). Higher levels of personal mobilitymore car ownership, more foreign holidays - have been accompanied by a greater awareness of other cultures, and there is also more international coverage on television, including satellite television, and more exposure to other lifestyles. Given that they were exposed to global products only quite recently, Turkish people are eager to consume the international brands in shopping malls that they have seen in Hollywood movies and foreign countries. During the recent economic crises, demand for exclusive international and domestic brands has survived much better than the goods from small local producers (Radikal 2001a). Demand to consume more, and more distinctively, has created a new consumption style that required new consumption and leisure spaces rather than small retailers and streets [for the changes in the Turkish retail industry, see Tokatli and Boyaci (1998)]. In a comparative study, Tokatli (1999) reported a restructuring in food retailers indicated by an immense growth of hypermarkets and supermarkets. This is mainly because of the emergence and strengthening of corporate power in this sector. The same applies to the construction sector, particularly when the crisis of the housing sector is considered (personal communication, K Sever, President of the Association of Constructors, 2001). Recently established real estate investments trusts (REITs) became the official market mechanisms for providing financial support to the construction sector (GYODER, 2002). As the housing demands-from luxurious housing for high-income groups to satellite towns for middle-income urban citizens - have been extensively satisfied, it is not surprising that other types of city building are of interest now. It is not very hard to promote shopping malls and office towers as a complement to well-established housing areas with the financial support provided by REITs. It should also be noted that such development also contributes to the increases in the market prices of the dwellings located in the vicinity (Onder, 2000; personal communication, A Kantur, Director of the Tepe Group and developer of Bilkent Shopping Center, 2000). 
Thus, shopping malls and office towers, as the complements of luxurious housing, are the responses of large capital, which has been looking for new investment areas. In a personal communication Kantur claimed that large investments in shopping malls are expected to dominate the construction sector in Turkey for another two to three decades. It should be noted that the recent economic crisis may reduce the rate of this trend, but the direction of development is expected to be the same. A new CarrefourSa mall (a joint venture between the French Carrefour and the Turkish Sabanci) opened in Ankara just after the February crisis (Radikal 2001c). Another, more luxurious one, called Armada, occupied by foreign brands and prominent Turkish firms, is the most recent addition to the Ankara malls, and began to operate in September 2002. An increasing contribution of foreign capital and international chains demonstrates the role of the global economy on urban spaces (Keyder, 2000; Tokatli and Erkip, 1998). Bozdogan (1998) points out the global influences on postmodern architecture in the Turkish urban scene, mainly in the form of satellite towns, office towers, hotels, and shopping malls. As she also claims (1994) that modernism in architecture was inhibited by the official ideology of the early Republican period, one can infer that late modernist development in architecture coincided with postmodern architectural forms. However, it is the new lifestyle that these sites propose, rather than their architectural characteristics, which attracts Turkish citizens awaiting a new outlook of modernity.

Thanks to the economic developments mentioned above, the consumption sites of today-particularly the malls - appear to be more democratic and public compared with the elitist past of public spaces and life in Turkey, although this aspect needs further analysis. In the next section I elaborate on the reasons for the elitist formation of Turkish modernity.

\section{Reestablishing Turkish modernity in public life}

After the establishment of the Republic in 1923, Western influence on Turkish society was deliberately sought and Western modernization dominated the Turkish national identity (Kasaba, 1998; Keyder, 1998). This identity was constructed from the top down by the Republican elite, and could not be overtly criticized for many years as multiple identities were seen as a threat to the Republican ideals and modernity of Turkey (Kasaba, 1998; Keyder, 1998). Bora (1996, page 194) states that the "ethocentric nationalism" emphasized cultural identity through Turkish citizenship, leading to a "xenophobic attitude towards the rest of the world". Religious identity was also suppressed by national identity (Ayata, 1993; Robins, 1996). Robins (1996, page 71) claims that the authoritarian state "has continuously denied the real diversity of civil society, which it can only comprehend in terms of social fragmentation, and against which it has mobilized the idealized fantasy of the Turkish people-as-one". Keyman (1997) further points out that Kemalism has itself turned out to be a tradition, which explains its long popularity despite its hegemonic character. However, the national modernization project has failed, and since the late 1980s, the various forces influencing the structure of Turkish society invited the identity debates in which multiculturalism turned out to be the most popular item on the agenda [see Helsinki Citizens Assembly, Turkey (2001), as an example of intensive discussions on this issue]. Among the major factors were: global economic and cultural influences; the hesitant position of Turkey as a candidate member of the European Union (EU); the increasing number of civil organizations formed by various segments of the Turkish population that is indeed multicultural-particularly religious groups and business communities. After 1980 the state's cultural politics also recognized Islamist tendencies as a dynamic cultural element missing in the early modernization of Turkey (Robins, 1996). Each segment of society - women, Islamists, ethnic groups - has been searching for an identity constructed by themselves without any intervention from the state and/or other dominating power. 
Recently, identity politics has begun to be one of the central themes in the Turkish political system (Ayata, 1997).

Under these circumstances, the last few decades witnessed extensive discussions and criticism of Turkish modernity, targeting a single national identity constructed upon Western values (Gole, 1998; 2000; Keyder, 1998). The rise of the Islamist movements and the increasing appearance of Islamists-particularly women-in public spaces are interpreted as the search for a new modernity (Aktas, 2000). Public space used to be dominated by the male population and although there were certain occasions in which women also participated, they were not a part of public life during the Ottoman period (Arat, 1998; Tokman, 2001). Women were given an active role in the transformation of the society in adopting Western values during the Republican period, and this role was supported by the increasing public appearances of Turkish women (Arat, 1998; Ayata, 1993). Now, a similar role has been undertaken by Islamist women. Shopping, previously dominated by the male as the decisionmaker, emerged as an appropriate activity for modern urban Turkish women. With the increasing number of women in the workforce-one third of the working population in 1990 (DIE, 2002) - they are expected to have a greater share in consumption. There are also indications that producers have become aware of the increasing role of women in new consumption patterns (Firat, 2001).

However, the demand for distinctive products and the influence of other cultures on Turkish consumption patterns are not unique. Abaza (2002) provides a similar observation on Egyptian consumerism, which indicates that globalization is not a starting point for establishing a consumer culture in all Eastern countries. Turkey is amongst those that were faced with this influence earlier. In this respect, the difference between Istanbul and Ankara should be noted at this point.

Even before the establishment of the Republic, Istanbul was the most affluent city in Turkey and the Ottoman elite in Istanbul tended to consume foreign products - both from the West and the East - to be distinct. The beginning of the 20th century witnessed the opening of a few international, mainly French, department stores such as Louvre, $\mathrm{Au}$ Lion, Bon Marche (Toprak, 1995). Istanbul had and still has a large mall-called Kapalicarsi, meaning 'closed mall' in Turkish-and it is claimed that the modern shopping mall has its roots in traditional Turkish society through Kapalicarsi (Tokman, 2001).

Istanbul is open to global influences, being the largest city in Turkey, with many international links and relations, whereas Ankara has always been more local in its business and population characteristics. Globalization in Turkey has always been matched with Istanbul, as the evidence suggests in spite of different interpretations (Aksoy and Robins, 1994; Keyder, 2000). Among the other popular sites of the global city, shopping malls find their place in Istanbul. The first malls were built in 1987 in Istanbul and in 1989 in Ankara. The number of shopping malls in Istanbul-more than twenty - is double that of Ankara (for the time being). The reasons for this gap are quite clear, yet also interesting due to the special characteristics of Ankara as the capital of the modern Turkish Republic, which makes the city representative of national values and lifestyles.

Governmental and educational institutions that are located in Ankara as parts of the modernization project have also contributed to the local character of the city (Tekeli, 1982; 2000). Tekeli (2000) claims that Ankara was a project of the Republic against the old values spatially represented by Istanbul. Istanbul was neglected by the Republican elite as the space of Ottoman Westernization and replaced by Ankara. This conflict between the two cities has been ongoing for years, with arguments about modernity, intellectual level, multiculturality, distinctive elite, and cosmopolitanism 
being made in favor of each according to different contexts. What should be noted is that Ankara has usually been in a defensive position vis-à-vis the cultural and architectural richness of Istanbul (Ergun, 1997). For the purpose of this study, an important aspect is that Ankara has been protected against any attack as the representative of national identity. Tekeli (1998) points out that the beginning of the global transformation in Ankara coincides with the restructuring in the national economic policies in the 1980s. Shopping-mall development in Ankara is interesting, as the control by agents other than corporate and global capital has been disappearing.

It should also be noted that shopping-mall development in Ankara reflects social and spatial segregation. Existing malls are shared between lower and upper social strata, according to the location and characteristics of the mall, mainly through the variety and quality of the goods and services provided by them. There is also evidence of segregation in leisure and recreational habits and sites, starting in the early Republican period. [See Senol (1998) for the early Republican period and Erkip (Beler) (1997) for a more recent account.] However, the global character of the mall providing various identity components under one roof gave way to a more heterogeneous and democratic consumption site, which has turned out to be a new public space in Turkish urban life. This aspect needs to be analyzed further from a theoretical perspective in order to understand the potential and problems of the mall for public life. Theoretical issues pertaining to the public character of the mall and the transformations created by mall development are discussed in the next section.

\section{The shopping mall as the emerging public space: theoretical concerns}

It is interesting to note that all these discussions on modernity, identity, and urban public life in Turkey have coincided with recent debates on the issues of global/local and modern/postmodern in contemporary urban analysis [see for instance, Albrow (1997), Eade (1997), Harvey (1989), Massey (1994), and Sassen (1991), for the first; and Giddens (1990), Mommaas (1996), and Savage and Ward (1993) for the second controversy]. Within this context, there exist conflicting beliefs about the source of place identity. Some (for example, Giddens, 1990; Philips, 1999) believe that the idea of locale' is at the core, whereas others (Massey, 1994; Williams and Kaltenborn, 1999) claim that global and local are required together and that multiple place identities can be a source of richness as well. Global modernity changes the very concept of place identity. Jewell (2001) further believes that the shopping mall is an appropriate space in which to observe an articulation of the global and the local, following Massey's (1994) arguments. Making spaces places for people requires local identity components. Global factors are inevitably modified to make shopping malls a part of the Turkish urban identity. Although malls are seen as representatives of postmodern city forms, Turkish society seems to be experiencing a 'transformational continuity', as proposed by Mommaas (1996), rather than a shift or discontinuity. The global influence comes with a mixture of cultures and lifestyles in most cases-rather than architectural characteristics. This mixture is the core of a new urban life with potential identity components. Yet, there is no doubt that place identity is necessary for individualization of the self and social order (Harvey, 1989). To claim that spatial homogenization leads to standardized consumption practices is to underestimate the cultural/local context (Crang, 1996; Jackson, 1999; Jackson and Thrift, 1995). Commodification of goods and services that may provide different individual identities through fragmentation works against standardization (Giddens, 1991). Abaza (2002, page 115) claims that shopping-mall development in Egypt "coincides with a discourse about purity". In the Turkish case, the discourse concerns modernity. 
In this paper I claim that the shopping mall serves as an extended milieu with spatial and social characteristics matching the new identity requirements of Turkish citizens. It also contributes to revising the meaning of the term 'flaneur' in relation to shopping and consumption (Featherstone, 1998; Wilson, 1992). Pollock (2000) highlights the link between flaneur and modernity with a particular focus on the exclusively masculine character of the flaneur. [See also Wilson (1992) on how urban life and commodified space changed the very meaning of flaneur.] The tendency to 'feminization of the flaneur' is mostly observed in privatized consumption sites (Abaza, 2002; Featherstone, 1998). Apparently, the malls currently provide modern well-maintained and guarded consumption and leisure spaces that are accessible by many segments of Turkish society (Tokman, 2001; personal communication 19 March 2002, I Tulgay, Technical Manager of Ankuva shopping center).

Durrschmidt (1997) proposes that people live in localities that contain various 'significant places' serving as extended milieus. The Turkish case represents a particular interaction between urban space and identity, where the shopping mall turns out to be an 'extended milieu' for Turkish urban citizens as one of the most 'significant places'. Breaking with the local is a popular trend, and an indication of modernity among many urbanites. What makes this process distinctive in Turkey is that people tend to invent modern lifestyle choices to replace the single uniform definition of modernity imposed by the Republican elite. Here, the notion of lifestyle is borrowed from Giddens (1991, page 81) as a "particular narrative of self-identity". Giddens also points out the importance of this concept in posttraditional settings. In that sense, Turkish modernity has only recently begun, and consumption has been the most appropriate realm in which people can find new lifestyle choices.

Another related issue is the promotion of authenticity as a part of global consumption trends (Giddens, 1991; Lewis and Bridger, 2000). 'Authentic others' are used together with the 'authentic local' to create the feeling of being elsewhere-either in other cultures or in a remake of the traditional past. An interesting view about this tendency to break with local ties is that of the huge use of cellular phones which is part of the extension. According to the results of a recent survey, 50.2\% of households in urban areas have access to mobile-phone technology, with at least one mobile phone per household in 2000 (TUBITAK-BILTEN cited by Suner, 2001). Suner (2001) further claims that the cellular phone serves as a symbol of 'global culture' providing the feeling of 'being elsewhere' - regardless of physical mobility. According to her, recent disasters - major earthquakes - and economic crises have caused people to think more about being elsewhere.

One of the most prominent issues in Turkish urban life is the feeling of 'otherness' that has been provoked recently as a result of economic and political polarization in metropolitan cities. Robins (1996, page 72) sees this process as a part of the true modernization through which "the 'other' Turkey is making its declaration of independence". However, the hostile feelings seem to be mutual as poor people think that some gain disproportionately without much effort (Demirel, 2001). In fact, there appears to be a hostile attitude toward the 'nouveaux riche' in Turkey with both upper and lower classes finding them vulgar and conspicuous. The squatter population are not homogeneous in their integration with urban life, which makes an urban lifestyle attractive to most of them-yet some feel completely excluded (Erman, 1998). According to Demirel (2001), urban people are more tolerant of differences regarding diverse lifestyles, a claim which should be tested for Turkish society under rapid transformation. Erman's (1998) work on a squatter settlement gives clues about the belongingness to the city, which is relatively independent of the years spent in the city-although there is a correlation in some cases. The reasons for becoming or not becoming urban are well 
documented and show no strict consensus among squatters. Besides, people living in legal settlements are also segregated to form various and conflicting identities in urban public life.

Zukin (1995; 1998) suggests that ordinary people negotiate urban public culture in ordinary shopping sites. Thus, replacing them with more privatized and controlled spaces may pose a threat to the future of the negotiation potential. Yet, one should be cautious about the applicability of Western generalizations to other societies. [See Drummond (2000), for the use of public and private spaces in urban Vietnam.] Open bazaars, parks, and particularly streets, have been crowded public spaces in Turkey despite the limited and controlled public sphere. However, in the Turkish urban context, there has been a territorial segregation through which districts are shared among the citizens. People usually share territories and sequences in the city, and some districts and spaces - public parks, streets - are negotiated, as Buffoni (1997) suggests. In terms of democratization and equality issues, "the globalized locality" of the mall seems very timely, "suggesting the possibility that individuals with very different lifestyles and social networks can live in close proximity without untoward interference with each other" (Albrow, 1997, page 51). The Turkish situation is, in this respect, quite different from that proposed by Lewis (1990) for the American mall, which forms a false setting of community. People experience the individuation of the self in the mall as a basic modernity requirement. Despite the potential for excluding people with technological devices and security guards, negotiation with cultural norms seems to apply inside the mall, rather than them being excluded at the gate. Instead, social and cultural codes apply to discourage some people (Mitchell, 2000; Zukin, 1997). There are indications that malls are shared by different income and cultural groups according to distinctive quality in Britain (Jewell, 2001); and to novelty and location in Turkey (Gokariksel, 2001).

Concern for security, which is used as one of the basic justifications for privatized spaces such as malls and gated communities, may not be a real threat in many cases. [See, for example, Ellin (1997) for the illusionary character of security threat in urban life.] There is no clear indication that security is a real reason for the development of privatized consumption spaces in Turkey, yet there are some clues which suggest they are attractive points for daytime burglary (Erkip, 2002(1) . Traffic conditions, infrastructure, and maintenance problems in the city center are important issues as well as crowding and social segregation. The perceived 'incivility of the streets' is the major factor behind privatized consumption spaces (Jackson, 1998). It applies to conditions of the streets in metropolitan cities of Turkey in many respects. People seem to find the modernity that they require in the privatized and controlled mall spaces instead of in the hardship and negotiation in other public spaces of the city.

In all the respects mentioned up to this point, Bilkent Shopping Center seems to be a very appropriate case for the discussion of interaction between the 'global' and the 'local'. Bilkent Shopping Center is the first mall in Ankara-and obviously not the last - aiming to attract visitors from all segments of society, and contains elegant, highclass products as well as lower priced and lower quality goods. Besides, it is the first suburban mall development with the character of a regional mall. Observations on site indicate that the Bilkent mall is successful as a new urban form of public space in Turkey. This is not to exclude the debate on privatization of public urban spaces. Seemingly, all the previous malls were dominated by particular user groups according to their location and quality. The establishment of Bilkent on an empty site with no

(1) $\mathrm{H}$ Ozdemir, the director of the Istanbul Security Department was also interviewed on 9 December 2001 by Tunca Bengin on TV2. 
history turns out to be an advantage for a global identity formation, despite the imaginary character of the created place (Helvacioglu, 2000). This made the space unique in lifestyle formation. In the following sections I document the field survey as an empirical investigation in a local context.

\section{The field survey}

In addition to various observations on the site, in-depth interviews were used to gather information on users' personal meanings. The results are presented below, after an overview of the Center.

\section{Bilkent Shopping Center: the emerging site of the modern public space}

Bilkent Shopping Center - built mostly in 1998 - is located approximately $15 \mathrm{~km}$ from the city center, near a recently established high-income housing settlement and a private university. (See figure 1 for the location of Bilkent Center relative to other consumption sites.) The entire environment is named after Bilkent University, which is an investment of Bilkent Holding owned by the family of the same name. The university was established in 1984, whereas the housing settlements have been ongoing investments, built in different phases with different characters, targeted mostly at the upper-income levels. The shopping center is within the reach of the surrounding neighborhood and attracts unexpectedly large numbers of users from the city as well. It can be considered as a regional mall, although it is smaller than that definition suggests (Crawford, 1992). It was completed in phases, like the dwellings, as the idea of building a shopping center was not part of the original development plan. For this reason, there was no initial overall design effort; this has resulted in incoherent structural and design characteristics (see figure 2, over, for a general view of the center). Now, it does not at all represent the design characteristics of a standard mall, as its layout lacks most of the 'familiar tricks of mall design' suggested by Crawford (1992). [See also Shields (1992) for the characteristics of a typical mall.] The section called Ankuva, in which most of the restaurants, coffeehouses, and quality shops are located, was first built to serve the neighbourhood. There are 69 shops including restaurants, and 30 of these are branches of exclusive domestic and international brands (Tulgay, personal communication, 2002). There are also branches of prominent banks and a recreation center with facilities for bowling, billiards, etc in Ankuva.

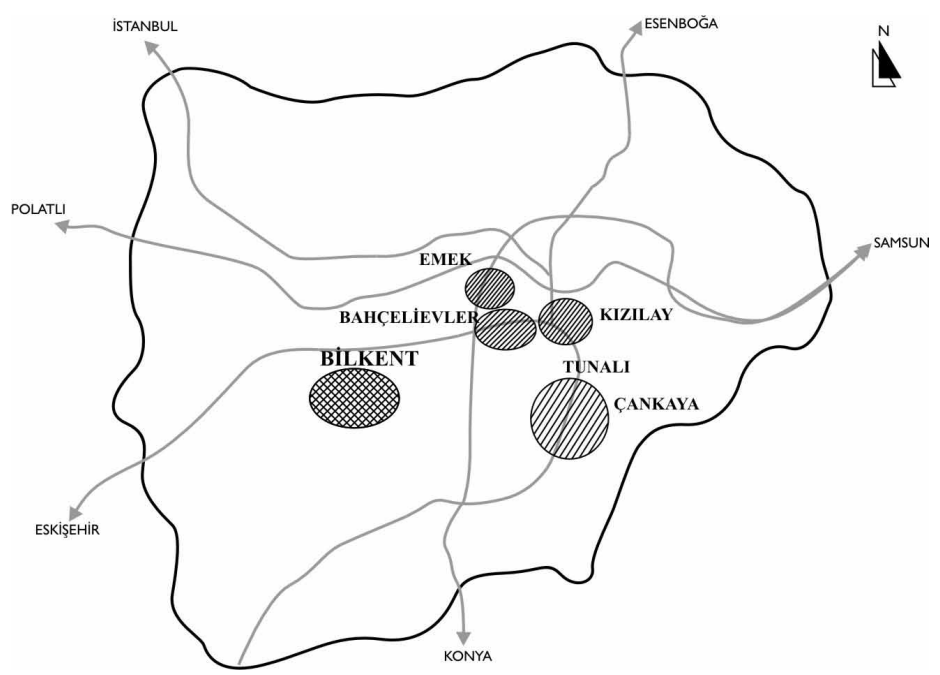

Figure 1. Location of the Bilkent Center (by Cilga Gurcel). 


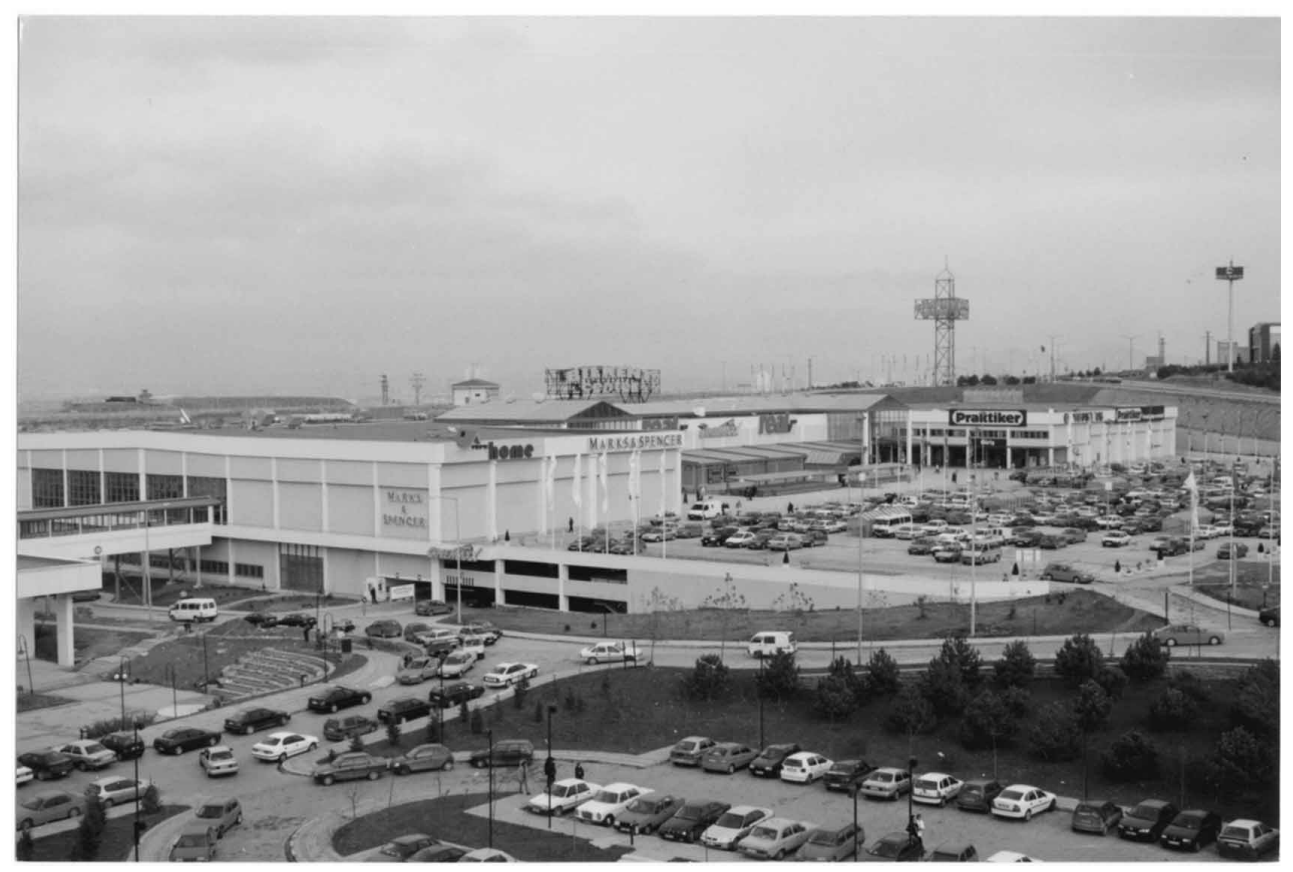

Figure 2. General view of the Bilkent Center (by Aydin Ramazanoglu).

However, seeing the future of the construction sector in Turkey and the global influences that are particularly influential upon the lifestyle of the well-off, developers decided to add a larger extension which is now used by Real and Praktiker, hypermarkets owned by German capital through Metro AG. Within this part, there is a small food court and small shops selling the products of international brands such as Sauder, Camel, etc. International fast-food chains serve food side by side with Turkish food chains selling traditional Turkish deserts and beverages. A dry-cleaning service is provided by Dryman. Similarly, Handyman in Praktiker provides transportation and interior-decoration services. The interesting point is that Handyman is a Turkish company, owned by Turgay Insaat, with an English name. Such fashionable use of English titles is also noted by Abaza (2002) in the Egyptian case. In addition, Marks and Spencer, Toys R Us, and Burger King are located within the center as well as an international movie theater-Cinemaxx. A huge home store owned by Tepe is another important attraction for consumers. Now, the overall shopping area is more than $60000 \mathrm{~m}^{2}$ (Soysal, 2001).

\section{On-site observations and evaluations of the service providers}

The creation of a new and global lifestyle in the area has been one of the prominent claims of the developers, which turned out to be a timely response to the demand of the people living in nearby settlements (Kantur, personal communication, 2000). Selfsufficiency was aimed at through providing facilities for all the needs of a global citizen, such as shopping, entertainment, education, and culture. There are kindergartens, elementary and high schools, and a concert hall in the area in addition to the university. One of the earlier slogans of the advertisements for the neighborhood was "let the city miss you". However, even the developers did not foresee the eagerness of people visiting such consumption and entertainment spaces and the traffic and transportation problems they caused. A daily average of 20000 people visit the center, which causes crowding and traffic jams around the center and the neighborhood. Car traffic is 
estimated at over 250000 vehicles per month (Tulgay, private communication). The use of pavements and restricted areas for parking has been becoming a regular practice around the center - a situation that resembles that in the city. Despite the global efforts to solve this - a German firm took over responsibility for traffic regulations-a local problem persists in making people's (both inhabitants' and visitors') jobs harder especially during weekends. There is also an ongoing road-maintenance issue on which neighboring communities have conflicting views (Tulgay, private communication).

In short, this area provides us with an opportunity to trace the formation of a new lifestyle under global influences. However, globally designed and labeled spaces are not sufficient to create the global citizen and his or her expected behavior. As indicated by Helvacioglu (2000), globally organized orientation programs for the employees of hypermarkets - to transform them into 'simulated people', as Ritzer (1999) puts itand traffic regulations devised by foreigners - in this case, Germans - cannot make the environment global. Helvacioglu (2000) calls this process 'glocalization', following Robertson (1995).

According to the observations made during the field survey, the number of male and female users appeared to be quite similar, even on weekdays. Previous research on the site also supports this observation (Aksel, 2000). This can be explained by the fact that one of the shops, Praktiker, sells construction materials and hence attracts male users working in the construction sector, as well as the increasing leisure character attached to shopping for both sexes. People from all age groups seem to use this site regularly, although there are more family visits during the weekends. According to the distribution of users' occupations, university students are the dominant group using the mall on weekdays, which may also explain the age factor: about $35 \%$ of the users on weekdays are students, a situation supporting the claim that the nearby university is a good source of consumers for this mall (Erkip, 2002).

Shopping is not an obligation, and involves leisure for most users. This situation has become more noticeable since the recent economic crises, which caused people to buy less - a frequent complaint of many shopowners (personal communications, 2001, 2002). However, exclusive brands targeting consumers with higher income levels have not been influenced by recession (Tulgay, private communication).

The shopping mall turns out to be a social environment as well as a leisure space. Most people come with others, mainly family members and friends. A sign warning parents against the use of shopping trolleys to carry their children throughout the mall is an indication of local understanding of family shopping. Meeting or accompanying other people makes the activity even more leisurely. On weekends, particularly Sundays, the mall exhibits a more heterogeneous character with users coming from distant districts, whereas local people prefer weekdays and Saturdays (personal communications, 2001, 2002, mall managers, shop owners, attendants). In this respect, the observation of Helvacioglu (2000) about the uniformity of users does not seem to agree with our experience. Another observation concerns the sharing of territories in the site among user groups. Ankuva is used mostly by higher income groups - mainly the people living in the vicinity and the students of Bilkent University - whereas the Real and Praktiker markets attract all types of visitor. This is supported by the interviews carried out with shop owners in the Ankuva section, who seem to be proud of their exclusive position (personal communications with shop owners, 2001, and Tulgay, 2002).

As a strong indication of global and local interaction, spatial arrangements are flexible: different occasions attract different user groups. In both the Ankuva and Real food courts, the restaurants reflect the emergence of an international taste. Mexican food is served side by side with traditional Turkish food in Real, 


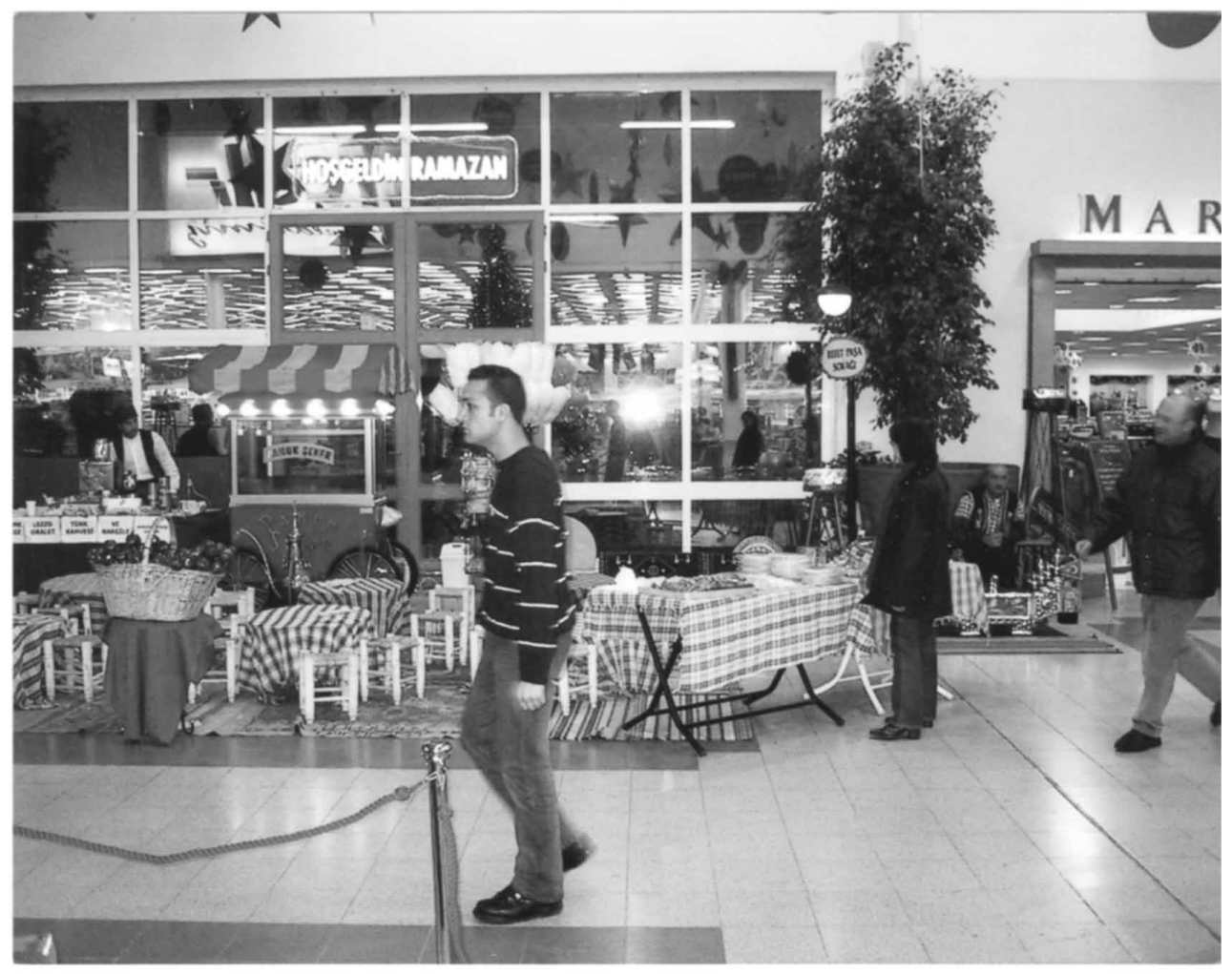

Figure 3. Temporary Turkish coffeehouse next to Marks and Spencer (by Kenan Ozduran).

whereas more expensive and classy restaurants are located in Ankuva. Hybrid tastes are observed in the mix of international brands and local ones (Abaza, 2002). For instance, during Ramadan - the Islamic ritual of fasting for one month-which coincided with the New Year in 2000 and 2001 due to shifting dates each year, the organization of space reflected both Muslim and Christian traditions, with a Turkish café inside the mall adjacent to Marks and Spencer (see figure 3). At the same time, the mall was decorated with Christmas trees. This flexibility in space use, and variety in goods and services, serve as a part of the process of creating 'socialized desire' (Langman, 1992). The Turkish coffeehouse represented in the mall is not an identity component for many urban citizens today, but is, instead, a rather nostalgic component. Celik (1994) evaluates this trend as a part of Western Orientalism seeing non-Western societies characterized by traditions and fixed in history. In the Ankuva section, an Indianesque gift shop - an authentic other culture-serves as an exclusive component, whereas in the Real section Turkish traditions - the Ramadan café and a traditional Turkish 'street' - provide authenticity. This is part of the effort to create a globalized locality through a mix of modern and traditional. Another point about authenticity is the marketing of authentic Turkish products-mainly textile products such as table cloths or bed covers - in the Real section, making previously distinctive products popular and less attractive for local elite. However, in a personal communication, Tulgay claimed that high-class Ankuva customers use Real and Praktiker from time to time, whereas the poorer people use Ankuva less frequently. 


\section{Evaluation of interviews: patterns in use of the shopping mall as a new site}

Structured interviews were conducted with predefined focus groups. Seventy-eight people were selected through purposive sampling to represent different user groups, with different needs and preferences. There were six focus groups, namely housewives (17), working women (17), university students (14), working men (13), teenagers (13), and retired persons (4). These groups appear to be the most frequent users of this particular mall, according to observation and the pilot study. A total of 78 interviews were carried out: it was not necessary to have equal numbers in each group as the qualitative analysis does not require a comparison or generalization. A summary of the characteristics of each group is given in table 1 (see over).

The most prominent findings can be summarized as the increasing role of leisure in shopping, indicated both by the activity patterns and by the frequent use of various malls for nonshopping activities, and the tendency for shopping malls to replace previously used urban public spaces. All of these indicate a change in the lifestyle patterns of mall users.

As a last step in the analysis, the particular characteristics of user groups or individuals within them were investigated to enrich the evaluation.

An interesting finding concerns the frequency of visits: there are two clusters, very frequent and less frequent, with few in between. The less frequent users were predominantly women, including 13 housewives. Another unexpected finding concerned duration of stay: people tend not to stay long - most stay $1-2$ hours (11 housewives), or 2-4 hours (including working people). Those who stay more than 4 hours comprised 4 working women, 1 working man, and 4 teenagers, indicating that there is no clear segregation in terms of a working/nonworking dichotomy. The housewives' position, indicating a limited use of the mall both in terms of frequency and duration is quite notable. It seems that either they seek leisure elsewhere, or their leisure time may be more limited than might be expected. [See Miller (1995) for the housewife as a mistakenly core image in consumption studies.] This reflects a different pattern from that found by Schor (2000), who suggests that Americans sacrifice leisure time to afford increasing consumption requirements. Turkish people tend to merge their leisure time with working hours as many jobs, particularly in public and governmental offices, permit such breaks because of variable workload. Besides, most people cannot earn enough to buy their time for leisure. Others have flexible working hours because they are self-employed, or work at Bilkent University. The housewives, the retired, teenagers, and university students come from nearby districts, whereas the working women and men come from various districts. There is no clear difference in their preferred visiting time: all groups use the mall on weekdays and during weekends, with the only dominance found being weekday usage by university students. (Students attending classes at Bilkent University tend to spend their free time in this mall during the weekdays.)

All groups combine shopping and leisure with the exception of teenagers, who use only the leisure facilities because of financial constraints. As stated by Vanderbeck and Johnson (2000, page 19) "... the mall is considered by many of the young people to be one of the few social/entertainment outlets available to them that did not involve either incurring safety risks or being 'on the streets." This is valid for the teenagers using Bilkent Shopping Center. However, the leisure aspect seems to be dominant for all groups: only 5 people of the 78 use the mall only for shopping. Despite the claim of providing a secure environment in the mall, the recreation center - the Roll House, which is the only place selling alcoholic drinks other than two luxurious restaurantsis mostly used by teenagers and has been the scene of some violence and vandalism (Tulgay, personal communication, 2002). 
Table 1. Frequency distribution derived from the interviews.

\section{Characteristics}

House- Working Working University Teenagers Retired

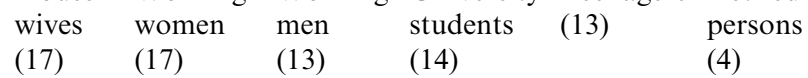

\begin{tabular}{|c|c|c|c|c|c|c|}
\hline \multicolumn{7}{|l|}{ Sex } \\
\hline male & & & 13 & 7 & 7 & 3 \\
\hline female & 17 & 17 & & 7 & 6 & 1 \\
\hline \multicolumn{7}{|l|}{ Age } \\
\hline $15-19$ & & & & & 13 & \\
\hline $20-45$ & 4 & 10 & 5 & 14 & & \\
\hline $46-65$ & 12 & 7 & 8 & & & 3 \\
\hline $65+$ & 1 & & & & & 1 \\
\hline \multicolumn{7}{|l|}{ Transport mode } \\
\hline private & 7 & 13 & 11 & 9 & 4 & 3 \\
\hline public & 7 & 3 & & 5 & 6 & 1 \\
\hline walking & 3 & 1 & 2 & & 3 & \\
\hline \multicolumn{7}{|l|}{ Duration of visiting } \\
\hline from the beginning & 6 & 10 & 7 & 9 & 10 & 2 \\
\hline 6 months -2 years & 9 & 7 & 6 & 5 & 3 & 1 \\
\hline less than 6 months & 2 & & & & & 1 \\
\hline \multicolumn{7}{|l|}{ Frequency of visits } \\
\hline more than 3 times a week & 4 & 4 & 7 & 10 & 7 & \\
\hline $1-2$ times a week & & 3 & & & & \\
\hline a few times a month or less & 13 & 10 & 6 & 4 & 6 & 4 \\
\hline \multicolumn{7}{|l|}{ Time of visits } \\
\hline weekdays & 10 & 7 & 6 & 10 & 7 & 3 \\
\hline weekends & 7 & 10 & 7 & 4 & 6 & 1 \\
\hline \multicolumn{7}{|l|}{ Duration of stay } \\
\hline $1-2$ hours or less & 11 & 8 & 8 & 8 & 4 & 1 \\
\hline $2-4$ hours & 6 & 5 & 4 & 6 & 5 & 3 \\
\hline more than 4 hours & & 4 & 1 & & 4 & \\
\hline \multicolumn{7}{|l|}{ Activities } \\
\hline shopping only & 2 & & 3 & & & \\
\hline leisure only & 4 & 3 & & 4 & 8 & 2 \\
\hline both & 11 & 14 & 10 & 10 & 5 & 2 \\
\hline \multicolumn{7}{|l|}{ Mode of visit } \\
\hline alone & 0 & 1 & 0 & 0 & 0 & 0 \\
\hline with friends and family & 11 & 9 & 9 & 11 & 10 & 4 \\
\hline both & 6 & 7 & 4 & 3 & 3 & 0 \\
\hline \multicolumn{7}{|l|}{ Use pattern } \\
\hline extensive & 15 & 17 & 11 & 12 & 10 & 4 \\
\hline limited targets & 2 & & 2 & 2 & 3 & \\
\hline \multicolumn{7}{|l|}{ Other mall usage } \\
\hline yes & 17 & 17 & 12 & 14 & 13 & 3 \\
\hline no & & & 1 & & & 1 \\
\hline \multicolumn{7}{|l|}{ Previously used spaces } \\
\hline small shops/markets/wholesalers & 14 & 5 & 10 & 9 & 4 & 3 \\
\hline urban core/high street & 3 & 12 & 3 & 3 & 8 & 1 \\
\hline \multicolumn{7}{|l|}{ Attitude/habit change } \\
\hline yes & 7 & 9 & 10 & 7 & 5 & \\
\hline no & 10 & 8 & 3 & 7 & 8 & 4 \\
\hline \multicolumn{7}{|l|}{ Internet shopping } \\
\hline yes & & & 2 & 3 & 1 & \\
\hline no & 17 & 17 & 11 & 11 & 12 & 4 \\
\hline \multicolumn{7}{|l|}{ Intention to use Internet for shopping } \\
\hline yes & 1 & 3 & 6 & 3 & 5 & \\
\hline no & 16 & 14 & 7 & 11 & 8 & 4 \\
\hline
\end{tabular}


With the exception of one working male and one retired person who use only this mall, all the interviewees regularly use other malls as well. Distance is the dominant reason for attending a particular mall, followed by the variety and the quality of goods. Interestingly the working women give the same reasons for choice but in the reverse order; this indicates the increasing mobility of Turkish urban women. Among the spaces previously used for similar activities, small shops and markets have been influenced most by the mall development, followed by open and closed bazaars. However, working women and teenagers mentioned urban core and high street $(9$ and 8 responses, respectively) as the previously used spaces. These were Kizilay-one of the two oldest city centers; Izmir street - the oldest pedestrian area; Tunali Hilmi street - the most prominent high street; and Emek/Bahcelievler-recently upgraded districts in the city (see figure 1). This is an indication that malls have attracted working women and teenagers from outside shopping and leisure patterns, whereas the other users have quit using the small shops and markets within the neighborhood. Attitude change appears to be a function of age, as the resistant groups are the teenagers and the retired, for differing reasons. However, some of the claims are not valid as many people give reasons for attitude change, even though they do not admit a change in their habits.

Besides the frequent, yet neutral, complaint about crowding in general, some people mention 'others' as a negative aspect of the mall. One adult male who lives in the neighborhood had complaints about the people coming from the city, claiming that they have no right to make life harder for himself and others living in the neighborhood. One female and two male university students also dislike other people, feeling that they are not elite enough. In contrast to this opinion, another adult male likes the site because of the elite visitors.

Almost everybody comes with friends or family and relatives, indicating the social aspect of the mall. The ratio of women visiting the mall on their own is higher than that of men ( 8 out of 17 for working women, 6 out of 17 for housewives), which can be viewed as a part of the image of modern women in urban Turkey. About one third of this group do not come for shopping. Abaza (2002) sees this pattern as the feminization of the flaneur that also occurs in Third World countries. Another supportive finding for this claim is that working women are the group using the mall most extensively, including Ankuva eating places, shops, and even the recreation center (4 women). Bowling, a new sport in Turkey, has been welcomed almost equally by both males and females in Bilkent Center (see figure 4, over, for the extensive use of the recreation center by this group). In all the other groups, except for the retired, there are a few people ( 9 in total) who do not use the Ankuva part, which is more upscale.

The reasons should be analyzed further as they may give clues about attitudes to 'others' or 'otherness'. Among those who do not use the Ankuva part, two housewives are less frequent users - coming to the mall only for shopping and eating and both find this section expensive. This is an indication of the influence of income level on the usage of an upscale shopping and eating area. Two working men also come to the mall for shopping and eating (one is a frequent user) and use this place because of the variety of goods. Their stated reason for not using the Ankuva section is the limitation of their leisure time. Two university students, not from Bilkent University or the neighborhood, are both females and live in lower-middle-income districts of the city. They use the mall for extensive purposes and like to find everything in one place. The interesting point is that one of them finds the space is too complex and the other dislikes the other people using the mall. The three teenagers - one female student, one female high school graduate, and one male worker-are inhabitants of low-income districts of Ankara. They all come with family and friends and spend more than 4 hours on each visit, although they visit less frequently. They all mention the 'others' as 


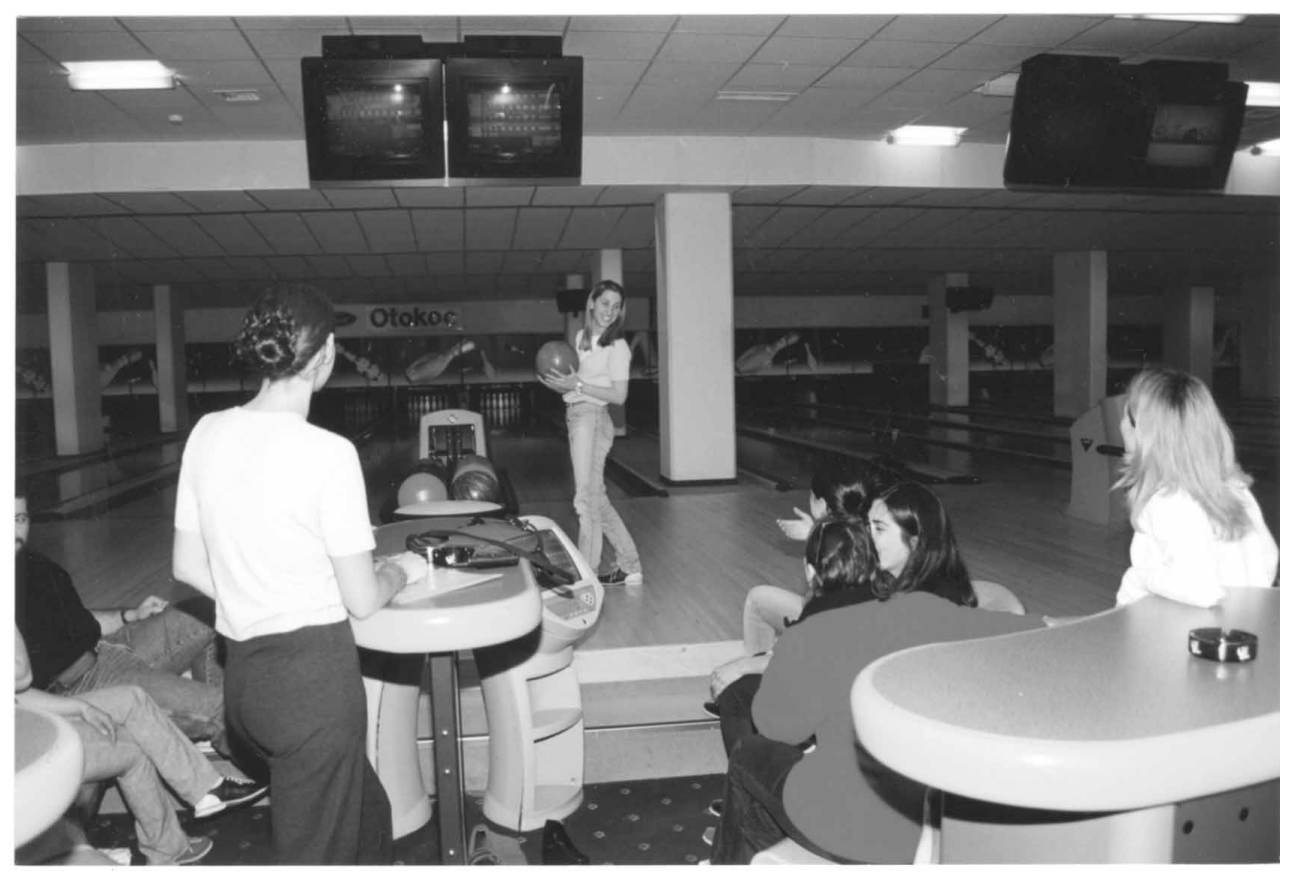

Figure 4. Female group bowling at the recreation center (by Murad Gurzumar).

either a liked or a disliked feature. The student finds the mall users 'high quality'. The high school graduate finds other people interesting and different and likes to watch them. The worker likes the ambience, but finds everything expensive, and likes to gaze at other users. Although the scope of these interviews is limited, it seems that younger people seem to be less tolerant of 'different others'.

The use of the Internet for shopping was asked about to determine the potential of e-commerce as an alternative to malls. This appeared very limited, as only 6 people (3 university students, 2 working men, and 1 teenager) have ever used the Internet for shopping. Declared intention to use it was limited to 18 people, among whom working men and teenagers were dominant. The reasons given for not using the Internet varied according to gender: the lack of sensory experience is important for housewives and working women, whereas security is important for working men. Lack of knowledge (slightly less for university students) or lack of an Internet connection (slightly more for teenagers) were reasons given by members of all groups.

It seems that the shopping mall will persist in being the most prominent consumption and leisure site in Turkey. Mall development is expected to expand to smaller cities and towns (Kantur, personal communication, 2000). Although the results of the survey give clues about the consumption patterns in a metropolitan city, both similar and different patterns might occur in the future to keep mall development on the agenda in Turkey for some more time.

\section{Concluding remarks}

Shopping malls are the most important additions to urban life in Turkey in terms of civilization, modernity, and the democratization of consumption patterns. Their impact does not seem to be limited to the field of consumption only, as they form a new identity combining global and the local. At the current stage of Turkish modernization, they appeared very timely in satisfying the requirements for a new modernity expressed 
by all segments of Turkish society. Although people seem to be more interested in the location, facilities, and variety offered by these new spaces, rather than their design characteristics, they are impressed by the modern and clean environment as an indication of a civilized society. They tend to use more than one mall frequently, making the mall an alternative to the city center. This issue needs to be addressed further as it has important policy implications for the future of Turkish urban life and the city center. This aspect is particularly important for Ankara, which has been the most prominent space exemplifying Turkish modernity and urban culture until recently. Now, it has become a part of the globally influenced transformation in Turkey.

However, cultural influences can be seen in the spatial organization and management of the mall (Tulgay, personal communication, 2002). It is apparent that shopping is merged with leisure for all user groups. The fact that working people use the mall extensively for longer periods is a good indication of extensive leisure use. This finding seems to contradict Jackson's (1999) claim of "the routine and mundane character of everyday consumption practices" (page 25) that still persists according to an empirical survey of two malls in England. [See Miller et al (1998) for details.] Yet, browsing and socializing are indications of leisurely use of these consumption sites. Although the mall experience in Turkey is too new for us to draw conclusions about consumption and identity issues, there is evidence for the use of the mall as a site for the new Turkish modernity. The present study can be seen as an initial attempt to raise questions on the function of the mall in shaping new urban identities in Turkey.

Another issue that may have implications for the future and for urban policy is the heterogeneous character of mall users. The malls invite and attract all age and income groups at present, which may be interpreted as a democratic consumption pattern. However, attitudes towards other users, which represent the tendencies of various groups, suggest otherwise. People tend to see the 'others' as different-both in positive and in negative ways - which is an indication of 'mutual feelings of otherness', if not yet hostility. This will definitely be a concern in Turkish shopping malls in the near future. Security threats, either real or perceived, will couple with this tendency of 'otherness' and provide an excuse for increasing private control over such spaces. Tulgay (personal communication, 2002) defines a group as suspicious according to their appearance and ethnicity, but defined the group using Ankuva as 'elite'. However, the spatial structure and organization of this particular mall provide diverse identity components which blur the issue of social segregation. People usually find these spaces secure, although security is not one of their stated reasons for visiting. The security problems which occur from time to time have a similar character to those that may occur in other parts of the city (Tulgay, personal communication, 2002).

In their study, Vanderbeck and Johnson (2000) evaluate malls as appropriate sites for young people (see also Lewis, 1990). This view is supported by Abaza (2002), despite cultural differences between Western and Eastern youth. The reasons for this group coming to malls are similar in Turkey, yet the fear of traffic is a more dominant concern both for them and for their parents than is the fear of crime or sexual harassment. Reported levels of vandalism and crime within the mall support the claim that the mall does not, in fact, provide a more secure environment, particularly for this age group.

Biases on gender roles in shopping and leisure have been dissolving, as male and female attitudes appear to be quite alike. This supports the findings of Otnes and McGrath (2001) challenging the stereotypes of male shopping behavior. It seems that what they call 'gender-role transcendence' is valid in this case. The bias on housewives, who were expected to be the most extensive mall users, was also not revealed. On the contrary, there are indications of extensive mall use by working women, both in terms of time spent and territory used in the mall, which may point to a tendency to 'feminization of 
the flaneur' (Featherstone, 1998). The mall provides this group with a modern and secure environment during the day and night, which cannot be found in the city centerparticularly at night. Gender differentiation seems to be less prominent in the mall space, although there have been a few incidences of sexual harassment (Tulgay, personal communication, 2002).

The results of this study support the claim that the mall as an emerging public space is turning out to be one of the most important sites for the transformation of Turkish urban life. However, the space itself is not the primary force leading to changes in consumption and leisure patterns. Rather, the demands of urban citizens to reestablish modernity coincided with the globalization efforts of Turkish cities in a timely way. The changing leisure and consumption patterns of Turkish people, under global influences, made this spatial transformation possible. The shopping mall is the space where the global and the local meet successfully, yet with potential problems. Time is needed to see how they form the Turkish experience.

Acknowledgements. The field survey was supported by the Faculty Development Research Grant program of Bilkent University. The author would like to thank Nesim Erkip, Nebahat Tokatli, and anonymous reviewers of EPA for their helpful comments on the earlier versions of this paper; Erol Emre Oktar, Fulya Oner, Baris Ozdamar, Zuleyha Baylaz, Fatih Cebecioglu for their assistance in data collection; and Andy Daventry for copy editing.

\section{References}

Abaza M, 2002, "Shopping malls, consumer culture and the reshaping of public space in Egypt" Theory, Culture and Society $1897-122$

Aksel B, 2000, "Is a commercial complex an urban center? A case study: Bilkent Center, Ankara", unpublished master's thesis, Middle East Technical University, Ankara

Aksoy A, Robins K, 1994, "Istanbul between civilization and discontent" New Perspectives on Turkey $1057-74$

Aktas C, 2000, "Kamusal Alanda Islamci Kadin ve Erkeklerin Iliskilerindeki Degisim uzerine: Bacidan Bayana" [On the transformation of the relationship between Islamist women and men in public space; from 'Baci' (sister) to 'Bayan' (lady, miss)] Birikim 13736 - 47

Albrow M, 1997, "Travelling beyond local cultures: socioscapes in a global city", in Living the Global: Globalization as Local Process Ed. J Eade (Routledge, London) pp $37-55$

Arat Y, 1998, "Turkiye'de Modernlesme Projesi ve Kadinlar" [Modernisation project and women in Turkey], in Turkiye'de Modernlesme ve Ulusal Kimlik Eds S Bozdogan, R Kasaba (Tarih Vakfi, Istanbul) pp $82-98$

Ayata A, 1997, "The emergence of identity politics in Turkey" New Perspectives on Turkey 17 59-73

Ayata S, 1989, "Toplumsal Cevre olarak Gecekondu ve Apartman" [Squatter and apartment block as social environment] Toplum ve Bilim 46/47 101 - 127

Ayata S, 1993, "Continuity and change in Turkish culture: some critical remarks on Modern Mahrem" New Perspectives on Turkey 9137 - 148

BKM, 2001 http://www.bkm.com.tr

Bora T, 1996, "Insa Doneminde Turk Milli Kimligi" [The constitution of Turkish national identity] Toplum ve Bilim $71168-194$

Bozdogan S, 1994, "Architecture, modernism and nation-building in Kemalist Turkey" New Perspectives on Turkey $1037-55$

Bozdogan S, 1998, "Turk Mimari Kulturunde Modernizm: Genel bir Bakis" [Modernism in the Turkish culture of architecture: an overview], in Turkiye'de Modernlesme ve Ulusal Kimlik Eds S Bozdogan, R Kasaba (Tarih Vakfi, Istanbul) pp 118 - 135

Buffoni L, 1997, "Rethinking poverty in globalized conditions", in Living the Global: Globalization as Local Process Ed. J Eade (Routledge, London) pp 110-126

Cizre-Sakallioglu U, Yeldan E, 2000, "Politics, society and financial liberalization: Turkey in the 1990s" Development and Change 31481 - 508

Celik Z, 1994, "Istanbul: urban preservation as a theme park, the case of Sogukcesme Street", in Streets: Critical Perspectives on Public Space Eds Z Celik, D Favro, R Ingersoll (University of California Press, Berkeley, CA) pp 83-92

Crang P, 1996, "Displacement, consumption, and identity" Environment and Planning A 28 47-67 
Crawford M, 1992, “The world in a shopping mall”, in Variations on a Themepark Ed. M Sorkin (Noonday Press, New York) pp 3-30

Demirel T, 2001, "Turkey's troubled democracy: bringing the socioeconomic factors back in" New Perspectives on Turkey $\mathbf{2 4} 105-140$

DIE, 19971994 Household Consumption Expenditures Survey Results State Institute of Statistics, Ankara

DIE, 19981994 Household Income Distribution Survey State Institute of Statistics, Ankara

DIE, 2002 State Institute of Statistics, http://www.die.gov.tr

Drummond L B W, 2000, "Street scenes: practices of public and private space in urban Vietnam" Urban Studies 372377 - 2391

Durrschmidt J, 1997, "The delinking of locale and milieu: on the situatedness of extended milieux in a global environment", in Living the Global; Globalization as Local Process Ed. J Eade (Routledge, London) pp 56-72

Eade J, 1997, "Introduction", in Living the Global: Globalization as Local Process Ed. J Eade (Routledge, London) pp $1-19$

Ekonomist 2001, "Alisveris Aliskanliklari Tamamen Degisti” [Shopping habits change completely] 11 (30 December - 5 January) $82-83$

Ellin N (Ed.), 1997 Architecture of Fear (Princeton Architectural Press, New York)

Ergun H, 1997, “Ankara Ne Degildir?” [What Ankara is not?] Birikim 102 89-91

Erkip F, 2002, "The rise of the shopping mall in Turkey: an analysis of the factors affecting the use and appeal of the mall through a case in Ankara", WP, Faculty of Art, Design and Architecture, Bilkent University, Ankara

Erkip (Beler) F, 1997, "The distribution of urban public services: the case of parks and recreational services in Ankara” Cities 14353 - 361

Erman T, 1998, "Becoming 'urban' or remaining 'rural': the views of Turkish rural-to-urban migrants on the 'integration' question" International Journal of Middle East Studies 30541 - 561

Erman T, 2001, "The politics of squatter (gecekondu) studies in Turkey: the changing representations of rural migrants in the academic discourse" Urban Studies 38 983-1002

Featherstone M, 1998, "The flaneur, the city and virtual public life" Urban Studies 35 909-925

Firat E, 2001, "Tuketim Egilimleri: Kadin Etkisi" [Consumption trends: the influence of women] Capital $984-88$

Giddens A, 1990 The Consequences of Modernity (Polity Press, Cambridge)

Giddens A, 1991 Modernity and Self-identity: Self and Identity in the Late Modern Age (Stanford University Press, Stanford, CA)

Globus 2002, "Kredi Karti Pazari Tam Gaz" [Credit card market is on its way] 3 (March) 25-26

Gokariksel B, 2001, "Istanbul'un Kulturel Haritasinda Galleria, Akmerkez ve Capitol'un Yeri: Mekan-Insan-Kultur Cozumlemesi Uzerine bir Deney” [The place of Galleria, Akmerkez and Capitol in Istanbul's cultural map: an experiment on the analysis of space-people-culture] Toplumbilim $14105-113$

Gole N, 1998, "Modernlesme baglaminda Islami Kimlik Arayisi" [The search for an Islamist identity in the context of modernisation], in Turkiye'de Modernlesme ve Ulusal Kimlik Eds S Bozdogan, R Kasaba (Tarih Vakfi, Istanbul) pp 70-81

Gole N, 2000 Islam ve Modernlik Uzerine Melez Desenler [Hybrid patterns on Islam and modernity] (Metis, Istanbul)

GYODER, 2002, Association of Real Estate Investment Companies, http://www.gyoder.org.tr

Harvey D, 1989 The Condition of Postmodernity (Blackwell, Oxford)

Helsinki Citizens Assembly, Turkey, 2001 Modernity and Multiculturalism (Iletisim, Istanbul)

Helvacioglu B, 2000, "Globalization in the neighbourhood: from the nation-state to Bilkent Center" International Sociology $15326-342$

Jackson P, 1998, "Domesticating the street: the contested spaces of the high street and the mall", in Images of the Street: Planning, Identity and Control in Public Space Ed. N R Fyfe (Routledge, London) pp 176-191

Jackson P, 1999, "Consumption and identity; the cultural politics of shopping" European Planning Studies $725-39$

Jackson P, Thrift N, 1995, "Geographies of consumption", in Acknowledging Consumption Ed. D Miller (Routledge, London) pp 204-237

Jewell N, 2001, "The fall and rise of the British mall" The Journal of Architecture 6317 - 377

Kasaba R, 1998, "Eski ile Yeni Arasinda Kemalizm ve Modernizm” [Kemalism and modernism between old and new], in Turkiye'de Modernlesme ve Ulusal Kimlik Eds S Bozdogan,

R Kasaba (Tarih Vakfi, Istanbul) pp $12-28$ 
Keles R, 2000 Kentlesme Politikasi [Politics of urbanisation], 5th edition (Imge, Ankara)

Keyder C, 1998, "1990'larda Turkiye'de Modernlesmenin Dogrultusu" [The direction of modernisation in Turkey in the 1990s], in Turkiye'de Modernlesme ve Ulusal Kimlik Eds S Bozdogan, R Kasaba (Tarih Vakfi, Istanbul) pp 29-42

Keyder C, 2000, "Arka Plan" [Background], in Istanbul, Kuresel ile Yerel Arasinda Ed. C Keyder (Metis, Istanbul)

Keyman F, 1997, "Kemalizm, Modernlik ve Gelenek" [Kemalism, modernity and tradition] Toplum ve Bilim $7284-101$

Koray M, 2001, “Gerceklerin 'Stilize' Edildigi bir Dunyada ‘Otekilesen' Yoksulluk” [Poverty becoming 'otherness' in a world of stylised reality] Toplum ve Bilim 89218 - 241

Langman L, 1992, "Neon cages; shopping for subjectivity", in Lifestyle Shopping: The Subject of Consumption Ed. R Shields (Routledge, London) pp 40-82

Lewis D G, 1990, "Community through exclusion and illusion: the creation of social worlds in an American shopping mall" Journal of Popular Culture 24121 - 136

Lewis D, Bridger D, 2000 The Soul of the New Consumer: Authenticity-What We Buy and Why in the New Economy (Nicholas Brealey Publishing, London)

Massey D, 1994 Space, Place and Gender (Polity Press, Cambridge)

Miller D, 1995, "Consumption as the vanguard of history: a polemic by way of introduction", in Acknowledging Consumption Ed. D Miller (Routledge, London) pp 1-57

Miller D, Jackson P, Thrift N, Holbrook B, Rowlands M, 1998 Shopping, Place and Identity (Routledge, London)

Mitchell K, 2000, "The culture of urban space", progress report Urban Geography 21443 - 449

Mommaas H, 1996, "Modernity, postmodernity and the crisis of social modernization: a case study in urban fragmentation" International Journal of Urban and Regional Research 20 $196-216$

Odekan A, 2001, “Istanbul'da Yaya Hakki Var mi?" [Are there pedestrian rights in Istanbul?] Istanbul $3748-51$

Onder Z, 2000, "High inflation and returns on residential real estate: evidence from Turkey" Applied Economics $32917-931$

Otnes C, McGrath M A, 2001, "Perceptions and realities of male shopping behavior" Journal of Retailing $77111-137$

Philips D, 1999, "Narrativised spaces: the functions of story in the theme park", in Leisure/Tourism Geographies: Practices and Geographical Knowledge Ed. D Crouch (Routledge, London) pp $91-108$

Pollock G, 2000, "Excerpts from 'Modernity and the Spaces of Feminity",, in Gender Space Architecture Eds J Rendell, B Penner, I Borden (Routledge, London) pp 154 - 167

Radikal 2001a, "Moda ve Alisveris" [Fashion and shopping], special supplement, 29 November

Radikal 2001b, "Sales (fire) are not put out", 3 December

Radikal 2001c, "Exported by Carrefour", 5 December

Radikal 2001d, "(They) are coming with the (credit) cards", 7 December

Radikal 2002, "Crisis cost 53 billion dollars", 1 April

Ritzer G, 1999 Enchanting a Disenchanted World: Revolutionizing the Means of Consumption (Pine Forge Press, Thousand Oaks, CA)

Robertson R, 1995, "Glocalization: time - space and homogeneity and heterogeneity", in Global Modernities Ed. M Featherstone (Sage, London) pp 25-44

Robins K, 1996, "Interrupting identities, Turkey/Europe", in Questions of Cultural Identity Eds S Hall, P DuGuy (Sage, London) pp $61-86$

Sassen S, 1991 The Global City: New York, London, Tokyo (Princeton University Press, Princeton, NJ)

Savage M, Ward E A, 1993 Urban Sociology, Capitalism and Modernity (MacMillan, London)

Schor J, 2000 Do Americans Shop too Much? (Beacon Press, Boston, MA)

Senol F, 1998, "Iktidar Mucadelesinin Savas Meydani Mekan: Cumhuriyet'in Ilk Yillarinda Ankara'da Eglence Mekanlari" [Battlefield of power struggle: space-entertainment facilities in Ankara at the beginning of the Republic] Toplum ve Bilim 76 86-104

Shields R, 1992, "Spaces for the subject of consumption", in Lifestyle Shopping: The Subject of Consumption Ed. R Shields (Routledge, London) pp 1-20

Soysal, 2001 Turkiye Perakende Katalogu [Retail catalogue Turkey] Soysal Egitim Danismanlik, M Pehlivan Street 20/2 Gayrettepe, 80290 Istanbul), http://www.soysal.com.tr/

Suner A, 2001, "Bir Baglanti Koparma Araci olarak Turkiye'de Cep Telefonu: Kriz, Goc ve Aidiyet" [Mobile phones in Turkey as a tool for disconnection: crisis, migration and belongingness] Toplum ve Bilim $90114-130$ 
Tekeli I, 1982, "Baskent Ankara'nin Oykusu” [The story of the Capital Ankara], in Turkiye'de Kentlesme Yazilari Ed. I Tekeli (Turhan Kitabevi, Ankara) pp 49-81

Tekeli I, 1998, “Turkiye'de Cumhuriyet Doneminde Kentsel Gelisme ve Kent Planlamasi” [Urban development and planning in Turkey in the Republican period], in 75 Yilda Degisen Kent ve Mimarlik Ed. Y Sey (Turkiye Ekonomik ve Topiumsal Tarih Vakfi, Istanbul) pp 1-24

Tekeli I, 2000, "Bir Modernite Projesi Olarak Turkiye'de Kent Planlamasi” [Urban planning in Turkey as a project of modernity], in Modernite Asilirken Kent Planlamasi Ed. I Tekeli (Imge, Ankara) pp 9-34

Tokatli N, 1999, "A comparative report on the profiles of retailing in the emerging markets of Europe: Turkey, Poland, Hungary, Portugal and Greece" Journal of Euromarketing 875 - 105

Tokatli N, Boyaci Y, 1998, "The changing retail industry and retail landscapes: the case of post-1980 Turkey" Cities 15345 - 359

Tokatli N, Erkip F, 1998, "Foreign investment in producer services: the Turkish experience in the post-1980 period" Third World Planning Review 20 87-106

Tokman A, 2001, "Negotiating tradition, modernity and identity in consumer space: a study of a shopping mall and revived coffeehouse", unpublished master's thesis, Bilkent University, Ankara

Toprak Z, 1995, "Tuketim Oruntuleri ve Osmanli Magazalari” [Consumption patterns and Ottoman stores] Cogito 5 25-28

Vanderbeck R M, Johnson J H, 2000, “That's the only place where you can hang out: urban young people and the space of the mall" Urban Geography 21 5-25

Williams D R, Kaltenborn B P, 1999, "Leisure places and modernity; the use and meaning of recreational cottages in Norway and the USA", in Leisure/Tourism Geographies: Practices and Geographical Knowledge Ed. D Crouch (Routledge, London) pp 214-230

Wilson E, 1992, "The invisible flaneur" New Left Review number 191, 90 - 110

Zukin S, 1995 The Cultures of Cities (Blackwell, Oxford)

Zukin S, 1997, "Cultural strategies of economic development and the hegemony of vision", in The Urbanization of Injustice Eds A Merryfield, E Swyngedouw (New York University Press, New York) pp $223-243$

Zukin S, 1998, "Urban lifestyles: diversity and standardization in spaces of consumption" Urban Studies $35825-839$ 